Dr. Craib's discussion of this problem has very general biological interest, as, indeed, do many of the contributions in this issue of Forestry, which seem primarily of economic interest.

Another very interesting ecological problem is the way in which the diversified native flora is sometimes superseded, as the result of fire or over-grazing, by almost pure stands of some particular plant. Mrs. Levyns gives a brief account of her extensive observations upon one such case, the extensive spread of the rhenoster bush, Elytropappus rhinocerotis, which has displaced pasture on the veld under such conditions. She shows that the seedlings of this plant flourish when germinating in completely exposed sites where many competitors wither and die, and that germination of the seeds may be better after exposure to a fireobservations which may explain the spread of this plant, which is useless as pasture. Sometimes the plants that oust the varied native flora are aliens, as several species of Hakea that cover the slopes of Table Mountain after fires.

\section{Grasslands.}

South Africa is now grazed much more closely by the stock of the settlers than was previously the case, when wild game alone roamed in the veld. For many miles, in the dry South African winter, the only fruiting grass haulms seen from the railway will lie inside the wire fence that protects the rail track from the stock. Outside this fence, every palatable plant is grazed ruthlessly down to soil level, and only plants with conspicuous powers of regeneration are able to survive the onslaught. The control of grazing so that future resources are not needlessly impoverished, is probably the line of surest advance in many agricultural problems, and the doyen of American agrostologists, Prof. A. S. Hitcheock, of the Smithsonian Institution, has a brief paper upon the relation of grasses to man, which, whilst it emphasises the great importance of these plants, is full of wise counsel as to the conservation of grazing land based upon the experience of the United States, where over-grazing with the consequent depletion of the range has been a pressing problem, as indeed it has always been in the history of stock raising on open grassland since the days of Abraham.

The paper by Messrs. R. R. Staples and A. J. Taylor upon pasture management shows that South Africa is already attacking its own problems in this field. They show that frequent clipping on the veld, to simulate close grazing, materially affects the normal grass flora, both the dominant species, Themeda. triandra, and the coarse pioneer grass, Eragrostis alba, succumbing very early under such treatment, whilst an introduced pasture grass, Paspalum dilatatum, survived the treatment much better. One of the most important results so far obtained in grassland management is undoubtedly the dominant significance of phosphate deficiency in most South African soils. Dr. I. de V. Malherbe states that phosphate treatment of arable soils practically always gives a large increase in yield, and Dr.P.J. du Toit emphasises the fact that phosphate manuring of grasslands in the form of bone meal has revolutionised the cattle industry in certain parts of South Africa. He suggests that, with a small daily ration of the missing mineral, it should be possible to raise improved breeds of cattle on the veld. A number of other very interesting contributions, dealing with both the native fauna, the stock and the economically important pests of the cultivator, are also included in this " Report of the 27th Annual Meeting of the South African Association "; in this review it has been possible to mention only very cursorily some of the many contributions that deal mainly with South African vegetation under both natural and cultivated conditions.

\title{
Weather and Climate of the Sahara.
}

$\mathrm{O}^{\mathrm{U}}$

TSIDE the polar regions there is no extensive area of land the weather and climate of which has been so little studied as that of the Sahara, with the possible exception of Central Asia. A certain romantic glamour seems to attach itself in the minds of most of us to that vast and little-known desert region, and this gives additional interest to a memoir published by the Meteorological Office, Air Ministry (Geophysical Memoir No. 48), which discusses in detail the meteorological observations made by $\mathrm{Mr}$. Francis Rennell Rodd in 1922 and 1927 in various parts of the Southern Sahara ranging from Timbuktu in the west nearly to Lake Chad in the east, and in latitude from about $12^{\circ} \mathrm{N}$. to $20^{\circ} \mathrm{N}$.

This is a region that owes its rainfall to a brief monsoonal incursion of south-westerly winds from the southern Atlantic during the late summer. These winds penetrate underneath the prevailing easterly or north-easterly winds, probably to a height of about 1 kilometre, and the rainfall appears to be generally of a vigorous convectional type; the convection apparently mixes the opposing wind currents and often leaves the easterly wind in temporary occupation of even the lowest layers. Occasionally this process gives rise to 'tornadoes' of the African type, which are of the nature of line squalls, not destructive vortices like American tornadoes; they give severe gales of short duration. The rainy season appears to be a complicated affair, interrupted by various breaks. There was an important autumnal part until about fifteen years ago according to the natives, and Mr. Rodd experienced a cloudy spell in late November and early December that yielded a few drops of rain and lent colour to the local tradition. He was not of the opinion that any important general desiccation of this part of Africa has been in progress either recently or during past ages.

As in many other parts of Africa, the more mountainous districts tend to get abundant rain, while the relatively low-lying plains not only have, on an average, a very small annual fall, amounting locally to less than five inches, but also one that is capricious, and in large areas a scanty desert vegetation is only precariously maintained.

It is not in regard to rainfall, however, that the interior regions of the Sahara yield the most interesting. weather, but in the matter of low relative humidity and the temperature contrasts that arise from it. Unfortunately, the degree of dryness experienced when easterly or north-easterly winds hold sway is too great for trustworthy treatment by normal hygrometry, and it would be necessary to make special direct absolute determinations to measure accurately the minute fraction of possible watervapour pressure contained by the air on those days when temperature rises to $114^{\circ}$, as happened in June 1922 and September 1927. Some idea was obtained by assuming that the vapour pressure remained constant between the cool early morning, when measurements by ordinary means could be relied on, and the time of greatest heat at 3 P.M., so that the relative humidity was governed by air temperature alone. There was reason for believing such an assumption to be nearly true; more than one calculation 
indicated a relative humidity of only five per cent, with a probability that two per cent may be attained at times.

The diurnal range of temperature is so great that, in spite of the very high day temperatures, frost is not unknown. On Dec. 14, 1922, the air temperature measured on a march by sling thermometer was $92^{\circ}$ at 2.30 P.M., and during the ensuing night in camp the minimum was $31^{\circ}$.

\section{University and Educational Intelligence.}

London.-A Bayliss-Starling Memorial Scholarship has been founded by old students, friends, and admirers in commemoration of the late Sir William Bayliss and Prof. E. H. Starling. The annual value of the scholarship is about $£ 120$, with exemption from tuition fees, and it is tenable at University College. The Scholar will be required to follow a course of study approved by the Jodrell professor of physiology, involving a training in the principles of, and methods of research in, physiology and biochemistry. Candidates must send their applications to the Secretary of University College not later than Wednesday, May 14.

As election of junior Beit fellows for medical research will take place in July next. 'The yearly value of each fellowship will be $£ 400$, and the tenure, ordinarily, three years. Forms of application (returnable on or before June 1) may be obtained by letter only, addressed to: Sir James K. Fowler, Honorary Secretary, Beit Memorial Fellowships for Medical Research, 35 Clarges Street, W.1.

Applications are invited from British subjects by the L.C.C. for two Robert Blair fellowships in applied science and technology, each of the value of $\mathfrak{1 4 5 0}$ and tenable for one year in the Dominions, the United States, or other places abroad. Particulars and application forms (T3/300) are to be had on application to the Education Officer ( $\mathrm{T}$. 3), The County Hall, S.E.1. The latest date for the return of forms is June 18.

UNIVERSITY CollegE, LoNdon, has just issued its report for the year ending February 1930, with statistics for 1928-29 showing a total enrolment of 3249 students, including 2399 whose homes were in the British Isles, 311 from the rest of the Empire, 52 from the United States of America, and 487 from other parts of the world. 1466 were in the different stages of degree courses, 523 were graduate and research students, 441 evening and 266 vacation students. In addition, free public lectures, among them seven by visiting professors from the continentDutch (2), Belgian, German (2), Swedish, and Danish universities-were attended by more than 14,450 persons, the aggregate number of attendances at the 67 lectures being 29,590. Among academic developments during the year was the establishment of a chair of American history for which the Commonwealth Fund of New York gave 214,500 dollars. The Centenary Fund, inaugurated three years ago to provide $£ 500,000$ for the completion of buildings and equipment and for endowment, amounted on Jan. 31, 1930 , to $£ 223,860$. The office of Provost of the College, held for twenty-five years by Sir Gregory Foster, on whom the honour of a baronetcy was conferred last New Year's Day, passed, as from the same date, to Mr. Allen Mawer, formerly Baines professor of the English language in the University of Liverpool.

No. 3155, VoL. 125]

\section{Historic Natural Events.}

April 20, r897. Aurora Australis.-A remarkable display of aurora was observed in the South Indian Ocean in lat. $47 \frac{1}{2}^{\circ} \mathrm{S}$. It began at 6.30 P.M. with a diffused light; horizontal flashes soon spread and flared in every direction, increasing in length and brilliancy, until at 7.30 P.M. they were shooting across the sky to within $30^{\circ}$ of the northern horizon. Cones and circles of light travelled rapidly over the whole sky, flashing beams of intense brilliancy from one to the other. This continued until 8.30 P.M., when an arch of bright green light fading off into yellow formed over the southern horizon, rose rapidly to a high altitude, and was followed by similar arches in regular sequence, until there were six distinct arches, their apices being from $10^{\circ}$ above the southern horizon to $60^{\circ}$ above the northern horizon. They were formed of narrow vertical bands of light from $5^{\circ}$ to $20^{\circ}$ deep, bright green and yellow at their upper edges, and of a rosy hie at their bases. At 9 P.M. a brilliant circle formed round the zenith, composed of narrow bands of light, pendant overhead and having a rotary motion, producing the effect of the vertex of an electrical cyclone. The display lasted until 9.45 P.M.

Apri1 22-25, I547. Red Sun.-In the whole of Germany, France, and England the sun appeared reddish and dull, like a ball with spots, so that the stars were visible (especially on April 24, during the battle of Mühlberg).

April 22, I884. Colchester Earthquake. - No British earthquake has resulted in so much damage to property as this shock. Within an area of $10 \mathrm{sq}$. miles to the south and east of Colchester, 1213 buildings and 31 churches had to be repaired. In Colchester more than 400 buildings were injured, while at three villages-Abberton, Peldon, and Wivenhoe-about 70 per cent of the chimneys were thrown down. The Colchester earthquake is one of the few British earthquakes that have been felt on the Continent, as at Boulogne and Ostend.

April 24, I579. Snow.-Holinshed records that snow fell in London between 4 A.M. and 9 A.M. to the depth of a foot. This is the more remarkable because, according to the present calendar, the date would have been early in May.

April 25-26, 1908. Great Snowfall.-This was one of the greatest spring snowfalls on record in the Midlands and southern England. About six inches of snow fell near London on April 24, but the heaviest fall occurred on April 25, accompanied by a strong gale in the English Channel. At Southampton, work at the docks was brought to a standstill, and throughout Oxfordshire, Berkshire, and the north of Hampshire all traffic by road was held up and communication by rail was maintained only with the greatest difficulty. The thaw caused a severe flood in the Thames.

April 25, 1926. Floods.- Owing to a rapid thaw of the heavy snows of the preceding winter, the rivers of Russia were in flood, all the low-lying parts of Leningrad, Moscow, and many other towns being under water. The damage was accentuated by blocks of drifting ice.

April 26-28, 1867. Gale and Floods in Brisbane.Rain commenced to fall on April 26 and continued throughout April 27, becoming torrential on April 28. On this day the wind rose to gale force, doing much damage. The river rose rapidly to an abnormally high level, and the banks were covered by debris from the valley. The lower parts of Brisbane were flooded.

April 26, I902. Green Flash.-Mr. C. T. Whittmell records in the Journal of the British Astronomical 